he received the Hon. Gold Medal of the Royal College of Surgeons of England, and the Prix Fauvelle of the Anthropological Society of Paris. He had delivered the Croonian Lecture, the Arris and Gale Lecture, the Huxley Lecture of Birmingham, the Imperial College and the Royal Anthropological Institute, as well as lectures of like standing in the medical colleges of Edinburgh, Dublin and the University of New York. He had been president of the Anatomical Society and the Manchester Literary and Philosophical Society among other societies concerned with his special studies, and his work had been recognized on the Continent by honorary fellowship or corresponding membership of the academies and more important anthropological societies of France, Holland, Belgium, Germany and Italy.

\section{Dr. C. V. Jackson}

DR. C. V. JACKSON, who at the early age of thirty years lost his life in a sleigh accident at St. Moritz on December 30, was a spectroscopist of considerable ability who had made valuable contributions to the establishment of accurate standards of wave-length. A graduate of the University of Oxford, he joined the Imperial College of Science and Technology about six years ago for the purpose of carrying on research in this subject under the direction of Prof. A. Fowler. On Prof. Fowler's retirement in 1934, he remained at the Imperial College as an honorary lecturer. His work included very precise interferometric measurements of iron, silicon, krypton and other spectrum lines, which were published in the Proceedings of the Royal Society, and he gave a considerable amount of attention also to the investigation of possible sources of light for the production of more satisfactory primary and secondary standards than those now accepted.

Dr. Jackson was a man of considerable financial resources, which he expended freely in the purchase of apparatus of the highest quality. His scientific work was characterized by quickness of mental apprehension and by an extreme fastidiousness in measurement which was in surprising contrast to the somewhat bewildering vagaries of his general temperament. He would alternate periods of intensive physical research with horse-racing and other social activities which are not usually found in such close association therewith. He was a member of the Commission on Wave-Length Standards of the International Astronomical Union, and attended the meetings of that body in Paris in 1935.

\section{Dr. J. M. H. Munro}

BEFORE 1884, basic slag was a 'waste product', of which extensive spoil heaps had accumulated. It was the refuse of Bessemer steel converters which had been lined with basic mineral matter to abstract phosphates from the molten iron, and it contained about twenty per cent of phosphorus pentoxide $\left(\mathrm{P}_{2} \mathrm{O}_{5}\right)$ combined mainly with lime. About forty years before that time, Lawes and Gilbert had demonstrated that the value of 'rock phosphate' as a fertilizer was greatly increased by treatment with sulphuric acid. The discovery by Wrightson and Munro of the fertilizing value of ground basic slag was of almost equal value to agriculture, and added vastly to the productivity of large areas of what were previously very poor pastures.

John May Herbert Munro, who died at Bath on November 6, at eighty-one years of age, matriculated at the age of seventeen and was one of the youngest men, if not the youngest, to graduate D.Sc. London five years later in 1877. His record included distinction in logic, botany and chemistry. In the early 'eighties, after having for a few years held an appointment in the Patent Office, he joined John Wrightson and William Fream in founding what was then the second of the English agrieultural colleges, at Downton in Wiltshire. John Wrightson was a brother of Thomas Wrightson, whose firm of steel manufacturers was one of those which had used the basic process and accumulated spoil heaps of slag. The high phosphate content of the slag was, of course, known, but it did not occur to anyone that it could be used as a fertilizer until Wrightson and Munro demonstrated the fact by a series of agricultural and laboratory experiments at Downton in 1883 and 1884.

I came to know Munro and to visit him at Downton about that time when he was working out methods of determining the solubility of the $\mathrm{P}_{2} \mathrm{O}_{5}$ of the slag, its availability as a plant nutrient and the degree of 'fineness of grind', on which both depended. His extreme modesty prevented him, so far as I know, from ever claiming credit for this demonstration of the value of finely ground basic slag, which later became well known from experiments by Gilehrist and Somerville at Cockle Park, in Northumberland. At the same time, Munro was working in collaboration with Warington on problems connected with nitrogen fixation by the nodules of leguminous plants, a subject then in its infancy, and on which he published papers in the Journal of the Chemical Society. In 1892, I was fortunate in obtaining his collaboration in a long series of experiments at Warminster on the factors of productivity and of malting quality in barley, and in the forty years following, during which they have been in progress, I have had the inestimable benefit of his advice on the chemical problems involved. Later on, he deserted professional agriculture (except as an analyst) for medicine and bacteriology, and did valuable work on the composition and therapeutics of Bath mineral water.

E. S. Beaven.

We regret to announce the following deaths :

Prof. Louis M. Dennis, emeritus professor of chemistry in Cornell University, an authority on gas analysis, on December 9, aged seventy-three years.

Prof. D. F. Fraser-Harris, formerly professor of physiology in Dalhousie University, Nova Scotia, on January 3 , aged sixty-nine years.

Geneviève Lady Watson, local secretary in Palestine to the Palestine Exploration Fund, on December 31 , aged eighty-two years. 